\title{
Detection of GBV-C/HGV RNA in Cervico-Vaginal Smears from Healthy Individuals
}

\author{
Maria Angelica Ehara Watanabe*, Ana Karina Melim Benthien Miquelão, Carlos Eduardo \\ Coral de Oliveira, Karen Brajão de Oliveira, Thiago Franco Nasser, Mateus Nóbrega Aoki, \\ Patrícia Sayuri Suzuki, Marla Karine Amarante, Emerson José Venâncio and Elbens \\ Marcos Minoreli de Azevedo \\ * Departamento de Ciências Patológicas; Universidade Estadual de Londrina; maewat@uel.br; 86051-970; \\ Londrina - Paraná - Brasil
}

\begin{abstract}
The purpose of the present study was to evaluate the sexual transmission of $G B V-C / H G V$, through RNA detection in cervicovaginal smears. Therefore the GBV-C/HGV RNA in cervicovaginal smears from apparently healthy women was investigated using routine proceedings for prophylactic screening to cervical cancer. GBV-C/HGV RNA was detected by reverse transcriptase and polymerase chain reaction (RT-PCR). Only one woman presented co-infection with human papilloma virus (HPV). The GBV-C/HGV RNA was detected in 13/73 (17.57\%) healthy women and it's prevalence in participating women between 28-43 years old was 53.85\%. No association was found with GBV$C / H G V$ for the age of first sexual intercourse and number of pregnancies. In GBV-C/HGV RNA positive women, $69.23 \%$ were married. In conclusion, the present findings show that cervical and vaginal specimens could contain the $G B V-C / H G V R N A$.
\end{abstract}

Keywords: GBV-C/HGV RNA, healthy women, cervicovaginal smears

\section{INTRODUCTION}

The GBV-C/HGV is an enveloped positivestranded RNA virus with a genome of about $9.4 \mathrm{~kb}$ belonging to the Flaviviridae family. Characterization of $\mathrm{HGV}$ and GBV-C showed them to be members of the family Flaviviridae (Simons et al., 1995; Linnen et al., 1996) and to contain a positive-polarity, single-strand RNA genome predicted to encode a polyprotein of approximately 3,000 amino acids. A sequence comparison demonstrated that $\mathrm{HGV}$ and GBV-C are different isolates of the same virus. Because subsequent studies did not find any association between these viruses and hepatitis, most researchers do not use the term $\mathrm{HGV}$ but refer to the virus as GBV-C (Stapleton, 2003). There are evidences that liver is not the primary site of GBV-C/HGV replication (Fabris et al., 1998). Persistent infection by GBV-C is common in humans and genetically divergent isolates have been identified in different parts of the world (Pavesi, 2001).

The $\mathrm{HCV}$ and GBV-C/HGV are two related members of the Flaviviridae, but they seem to behave differently from a pathogenicity standpoint. The absence of an immunogenic capsid protein in GBV-C/HGV may allow immune surveillance to be eluded and possibly, in this way, it is not subjected to immune selection, so that the

\footnotetext{
${ }^{*}$ Author for correspondence
} 
sequence of infecting isolate persists for long periods (Pilot-Matias et al., 1996). Using a yeast genetic system, it has been observed that IFNresistant GBV-C NS5A inhibited RNA-activated protein kinase (PKR) - mediated eIF2alpha phosphorilation suggesting a mechanism by which GBV-C may evade clearance by naturally occurring host antiviral responses (Xiang et al., 2005).

The GBV-C/HGV is transmitted mainly by parenteral route. Patients with chronic renal failure have a high risk of acquiring these viruses because they need frequent blood transfusions and undergo medical procedures that accompany bleeding (Castelain et al., 2004). In Brazil, there are data concerning GBV-C/HGV infection in hemodialysis patients (Watanabe et al., 2003; Ramos Filho, 2004). The GBV-C/HGV infection prevalence was found low in patients with $\mathrm{HBV}$ and HCV infections, supporting that although parenteral route is the most effective way, other routes such as sexual intercourse and intra-familial contact could also play an important role in the HGV transmission (Kaya et al., 2004).

The presence of GBV-C/HGV has no effect on the course of infection with hepatitis $\mathrm{C}$ virus (HCV) (Alter et al., 1997) or hepatitis B virus (HBV) (Wu et al., 1997), in coinfected individuals. Some evidences suggest that HIV-infected patients coinfected with GBV-C/HGV may experience a slower progression of HIV disease (Lefrère et al., 1999) and it has been found that HIV-positive people who are coinfected with GBV-C survive significantly longer than HIV-positive individuals without GBV-C infection (Stapleton et al., 2003; Stapleton et al., 2004). Expression of mRNA for RANTES, MIP- $1 \alpha$. MIP- $1 \beta$, SDF- 1 and secretion of the chemokines into culture supernatants were higher in GBV-C infected cells (Xiang et al., 2004). Recent evidence indicates that GBV-C E2 protein may neutralize HIV infection in vitro (George and Varmaz, 2005).

Actually, the HGV infection is found widely in human population. Until now many efforts have been made on the expression and replication of HGV in vitro, but many researchers have focused on the association of HGV with liver diseases. Recently it has been found that genomic RNA from full-length HGV cDNA is infectious to the Macaca mulatta and can cause mild hepatitis. $M$. mulatta is susceptible to the inoculated HGV, and therefore can be used as an experimental animal model for the studies of $\mathrm{HGV}$ infection and pathogenesis (Ren et al., 2005).

Epidemiological data suggest that this virus is also spread by sexual transmission (Bourlet et al., 1999). Because GBV-C is transmitted sexually, vertically, and by exposure to contaminated blood, populations with high rates of sexually transmitted diseases or blood-borne infections have high prevalence rates of active or prior GBV-C infection (Stapleton, 2003). This study enrolled 73 women ranged in age from 14 to 68 years, in order to examine the GBV-C/HGV RNA presence in the cervicovaginal smears samples.

\section{PATIENTS AND METHODS}

\section{Patients}

Following approval from the Human Ethics Committee of Londrina State University, cervicovaginal smears were collected from 73 Brazilian women. The samples were examined for the presence of GBV-C/HGV RNA. The specimens were collected from apparently healthy women under Pap smears routine proceedings for prophylactic screening of cervical cancer. The tests were performed without knowledge of colpocytology and clinical data.

\section{RNA extraction}

Cervicovaginal smears samples were soaked and vortexed gently in sterile phosphate-buffered saline. RNA was extracted using TRIzol-LS ${ }^{\circledR}$ reagent (Invitrogen, USA) according to the manufacturer's instructions.

\section{RT-PCR and Primers conditions}

cDNA synthesis - RNA (between 20-40 ng) from cells was reverse transcripted and amplified using GeneAmp Kit for RT-PCR (Perkin Elmer). Reverse transcription was carried out with 50 pmoles of the type-specific outer antisense primer using 50 units of cloned Murine Leukemia Virus $(\mathrm{MuLV})$ reverse transcriptase (Perkin Elmer) GeneAmp RNA PCR kit (Part number N808-

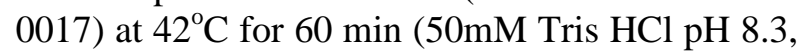
$75 \mathrm{mM} \mathrm{KCl}, 3 \mathrm{mM} \mathrm{MgCl} 2,200 \mu \mathrm{M}$ of dNTP) in the thermocycler (PCRSprint ThermoHybaid from Biosystems). 


\section{PCR conditions}

The GBV-C primers were used for the amplification of GBV-C RNA. The GBV-C primers were designed based on the sequence of GBV-C/HGV (GenBank sequence U44402) and were targeted to amplify the conserved 5' end (5' UTR) of the GBV-C/HGV genome (outer sense 5' GGTAGGTCGTAAATCCCGGT 3'; outer antisense 5' CCCACTGGTCCTTGTCAACT 3'; inner sense 5' TGGTAGCCACTATAGGTGG 3'; inner antisense 5' GCCTATTGGTCAAGAG 3'). Reactions conditions for the two PCR rounds were the same $(20 \mathrm{mM}$ Tris- $\mathrm{HCl} \mathrm{pH} 8.4,50 \mathrm{mM} \mathrm{KCl}$, $1.5 \mathrm{mM} \mathrm{MgCl} 2,200 \mu \mathrm{M} d \mathrm{dTP}$ and 1.25 units of Taq polymerase) and consisted of an initial denaturation step of $94^{\circ} \mathrm{C}$ for $5 \mathrm{~min}$ followed by 40 cycles of $94^{\circ} \mathrm{C}$ for $1 \mathrm{~min}, 45^{\circ} \mathrm{C}$ for $1 \mathrm{~min}, 72^{\circ} \mathrm{C}$ for $1 \mathrm{~min}$ and a final extension of $72^{\circ} \mathrm{C}$ for $10 \mathrm{~min}$ using thermocycler (PCRSprint ThermoHybaid). PCR products of 217 base pairs were analyzed by electrophoresis on acrylamide gel (10\%) for $1,5 \mathrm{~h}$ at $80 \mathrm{~V}$. After gel electrophoresis, the band intensity for $217 \mathrm{bp}$ was detected by a nonradioisotopic technique using a commercially available silver staining method (Oto et al., 1993). A negative control (water instead of cDNA) was included in all reactions. Specificity of the amplification products was demonstrated by DNA sequencing. To confirm the presence of GBV-C RNA, RT-nested PCR was repeated for all the positive samples, and in some cases RNA from patients' blood was obtained for the second time and also tested.

\section{Statistical analysis}

Data were analyzed by Student's test by Microcal Origin $^{\mathrm{TM}} 4.1$ Program with the level of significance set at $\mathrm{p}<0.05$.

\section{RESULTS AND DISCUSSION}

The worldwide prevalence of GBV-C/HGV on healthy populations is notably high, ranging from $2 \%$ on German blood donors (Stark et al., 1996) to $14.2 \%$ on West African residents (Dawson et al., 1996; Wiwanitkit, 2005). High prevalence of GBV-C/HGV RNA has also been demonstrated among Brazilian blood donors, being 9.7\% (Levi et al., 2003) and 12\% (Amarante et al., 2004). Figure 1 shows the analysis of cervicovaginal samples from healthy volunteers' women to detect GBV-C/HGV RNA by RT-PCR.

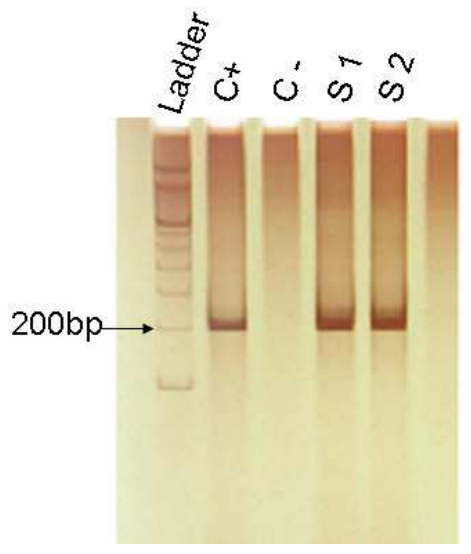

Figure 1 - GBV-C RNA detection in cervicovaginal smears. Peripheral blood cells RNA were screened for the presence of GBV-C RNA by nested RT-PCR as described in Material and Methods. L: Ladder is 100bp marker (Promega,Madison, WI). C+ is the positive control for GBV-C RNA and C- is the negative control. All positive samples demonstrated only $217 \mathrm{bp}$ product as demonstrated for S1 and S2.

In this work, GBV-C/HGV RNA was detected in 13 of the 73 donors (17.57\%). The oligos utilized to amplify GBV-C/HGV sequences are customly used in other studies in our laboratory, where PCR products had been directly sequenced. Sequence analysis revealed that the amplicons were compatible to GenBank accession U44402.

Recently, it has been suggested that male to male sex is a more effective mode of transmission of GBV-C (Berzsenyi et al., 2005). A significant 
trend of GBV-C/HGV RNA positivity in relation to age was observed, with the highest prevalence in donors between 29-39 years old men (Oliveira et al., 2002). As shown in Table 1, the similar values of age mean was observed in the presence or absence of GBV-C/HGV RNA but, in this work, in spite of only women, there was association between GBV-C/HGV RNA and age in which $\mathrm{GBV}-\mathrm{C} / \mathrm{HGV}$ RNA prevalence was detected in participating women between 28-43 years old $(53.85 \%)$.

Table 1 - Characteristics from study subjects GBV-C/HGV RNA positive and negative donors.

\begin{tabular}{lccc} 
& $\begin{array}{c}\text { Absence of GBV-C/HGV } \\
\text { RNA }\end{array}$ & $\begin{array}{c}\text { Presence of GBV-C } \\
\text { /HGV RNA }\end{array}$ & P value \\
\hline Average age (years) & $37.69( \pm 11.4)$ & $34.9( \pm 13.1)$ & 0.48 \\
Number of pregnancies & $4( \pm 2.2)$ & $3.6( \pm 3.3)$ & 0.36 \\
$\begin{array}{l}\text { Average age of first sexual } \\
\text { intercourse }\end{array}$ & $17.03( \pm 3.59)$ & $17.8( \pm 3.72)$ & 0.51 \\
\hline
\end{tabular}

No association was found with GBV-C/HGV for the age of first intercourse and number of pregnancies. In the GBV-C/HGV RNA positive women, $69.23 \%$ were married (Table 2). These results support the findings of others studies regarding the role of sexual transmission of GBVC/HGV (Sarrazin et al., 1997; Frey et al., 2002).

Potential transmission routes associated with parenteral $(30 \%)$, sexual (18\%), both $(6 \%)$ and intra-familiar (6\%) by GBV-C/HGV RNA positive donors have been demonstrated. However, $40 \%$ of them did not mention any known source for infection (Oliveira et al., 2002).

In the present study, the group of cervicovaginal group donors positive for GBV-C/HGV RNA, earned less than U\$ 150 per month (data not shown). This fact is compatible with Konomi et al. (1999), who related that low socioeconomic status and poor hygienic conditions occurring in developing countries could contribute to GBV$\mathrm{C} / \mathrm{HGV}$ dissemination. It has been proposed by Frey et al. (2002) that sexual activity and, possibly, the presence of sexually transmitted diseases (STD) increases the risk of GBV-C/HGV transmission. The presence of GBV-C/HGV RNA in the semen supernatant samples (33.3\%) and saliva samples $(6.6 \%)$ has been shown, but not in faeces and urine samples (Quiros-Roldan et al., 2001). These authors, therefore, hypothesize that semen or salivary contact could be involved in GBV-C/HGV transmission.

Table 2 - Marital status of women participating in the study

\begin{tabular}{lcc}
\hline & Absence of GBV-C/HGV RNA & Presence of GBV-C/HGV RNA \\
\hline Single & $28.33 \%$ & $15.38 \%$ \\
Married & $40 \%$ & $69.23 \%$ \\
Living together & $16.67 \%$ & 0 \\
Divorced/Separated & $5 \%$ & $7.69 \%$ \\
Widow & $10 \%$ & $7.69 \%$ \\
\hline
\end{tabular}

In a comparison between subjects with or without STD, Frey et al. (2002) have demonstrated that the prevalence of $\mathrm{GBV}-\mathrm{C} / \mathrm{HGV}$ was $36.6 \%$ versus $8.8 \%$, respectively, when results of PCR and enzyme-linked immunosorbent assay were combined, suggesting that the presence of a STD increases the risk of GBV-C/HGV. An extensive and diverse spectrum of pathogenic organisms may be observed in vaginal microbiota (Wanderlei-Silva et al., 2005). In spite of the wide ranging literature on the microbiology of normal and abnormal vaginal contents, many questions have still not been completely answered. Although studies by Souza et al. (2006) demonstrated that accurate detection of GBV-C RNA by nested PCR requires the use of primers representing multiple 
genome regions, the present findings showed that cervicovaginal specimens could contain GBV$\mathrm{C} / \mathrm{HGV}$ RNA. Whether this reflects active replication of such viruses in the female genital tract, for example by lymphoid cells or exudation from plasma remains to be established.

\section{ACKNOWLEDGMENTS}

We acknowledge the volunteers who made the study possible. This work was supported by $\mathrm{CNPq}$, CAPES and PROPPG-UEL.

\section{RESUMO}

O objetivo do presente estudo foi avaliar a transmissão sexual de GBV-C/HBV, através da detecção do RNA viral em raspados cérvicovaginais. Portanto, a presença do RNA GBV$\mathrm{C} / \mathrm{HGV}$ foi investigada em raspados cérvicovaginais em mulheres aparentemente saudáveis que realizaram exames preventivos para câncer cervical. GBV-C/HGV RNA foi detectado por reação de transcriptase reversa e reação em cadeia da polimerase (RT-PCR). Apenas uma mulher apresentou a co-infecção com o papiloma vírus humano (HPV). O RNA GBV-C/HGV foi detectado em 13/73 (17,57\%) mulheres saudáveis e sua prevalência entre participantes da idade de 28-43 anos foi de 53,85\%. Não foi observada relação entre a presença do RNA GBV-C/HGV com a idade de primeira relação sexual, nem com o número de gestações. Entre as mulheres que apresentavam o RNA viral, 69,23\% eram casadas. $\mathrm{O}$ presente estudo demonstrou que secreções cérvico-vaginais podem conter o RNA viral GBV$\mathrm{C} / \mathrm{HBV}$.

\section{REFERENCES}

Alter, H.J.; Nakatsuji, Y.; Melpolder, J.; Wages, J.; Wesley, R.; Shih, J.W.; Kim, J.P. (1997), The incidence of transfusion-associated hepatitis $G$ virus infection and its relation to liver disease. $N$ Engl $J$ Med; 336, 747-754.

Amarante, M.K.; Miranda, H.C.; Oliveira, C.E.C.; Oliveira, K.B.; Watanabe, M.A.E. (2004), Detection of $\mathrm{HGV} / \mathrm{GBV}-\mathrm{C}$ RNA in healthy individuals non carrier of HBV, HIV-1/2 and HCV. Semina Biológicas e Saúde; 25, 39-44.
Berzsenyi, M.D.; Bowden, D.S., Bailey, M.J.; White, C.; Coghlan, P.; Dudley, F.J. (2005), Male to male sex is associated with a high prevalence of exposure to GB virus C. J Clin Virol; 33, 243-246.

Bourlet, T.; Guglielminotti, C.; Evrard, M.; Berthelot, P.; Grattard, F.; Frésard, A., Luncht, F.R.; Pozzetto, B. (1999), Prevalence of GBV-C/hepatitis G virus RNA and E2 antibody among subjects infected with humaimmunodeficiency virus type 1 after parenteral or sexual exposure. J Med Virol; 58, 373-377.

Castelain, S.; Francois, C.; Bonte, D.; Baron, A.; Horle, B.; Morel, V.; Pautard, B.; Duverlie. G. (2004), Epidemiological and quantitative study of GBV-C infection in french polytransfused children. $\mathrm{J} \mathrm{Med}$ Virol; 73, 596-600.

Dawson, G.J.; Schlauder, G.G.; Pilot-Matias, T.J.; Thiele, D.; Leary, T.P.; Murphy, P.; Rosenblatt, J.E.; Simons, J.N.; Martinson, F.E.; Gutierrez, R.A.; Lentino, J.R.; Pachucki, C.; Muerhoff, A.S.; Widell, A.; Tegtmeier, G.; Desai, S.; Mushahwar, I.K. (1996), Prevalence studies of $\mathrm{GB}$ virus $\mathrm{C}$ infection using reverse transcriptase polymerase chain reaction. $J$ Med Virol; 50, 97-103.

Fabris, P.; Biasin, M.R.; Infantolino, D.; Romano, L.; Benedetti, P.; Tositti, G.; Pellizzer, G.P.; Zanetti, A.R.; Stecca, C.; Marchelle, G.; de Lalla, F. (1998), $\mathrm{HGV} / \mathrm{GBV}-\mathrm{C}$ in liver tissue and in sera from patients with chronic hepatitis C. Infection; 26, 283-287.

Frey, S.E.; Homan, S.M.; Sokol-Anderson, M.; Cayco, M.T.; Cortorreal, P.; Musial, C.E.; Di Bisceglie, A. (2002), Evidence for probable sexual transmission of the hepatitis G virus. Clin Infec Dis; 34, 1033-1038.

George S.L.; Varmaz D. (2005), What you need to know about GB virus C. Curr. Gastroenterol Rep; 7, 54-62.

Kaya, S.; Cicioglu, A.B.; Demirci, M. (2004), The prevalence of hepatitis $G$ virus in patients with hepatitis B and C virus infections. Mikrobiyol Bul ; 38, 421-27.

Konomi, N.; Miyoshi, C.; Zerain, C.F.; Li, T.; Arakawa, Y.; Abe, K. (1999), Epidemiology of hepatitis B, C, E and G virus infection and molecular analysis of hepatitis $\mathrm{G}$ isolates in Bolivia. $J$ Clin Microbiol; 37, 3291-3295.

Lefrère, J.J.; Roudot-Thoraval, F.; Morand-Joubert, L.; Petit, J.C.; Lerable, J.; Thauvin, M. (1999), Carriage of $\mathrm{GB}$ virus $\mathrm{C} /$ hepatitis $\mathrm{G}$ virus RNA is associated with a slower immunologic, virologic and clinical progression of human immunodeficiency virus disease in coinfected persons. J Infect Dis; 179, 783789.

Levi, J.E.; Contri, D.G.; Lima, L.P.; Takaoka, D.T.; Garrini, R.H.; Santos, W.; Fachini, R.; Wendel, S. (2003), High prevalence of GB vírus C/hepatitis G vírus RNA among Brazilian blood donors. Rev Inst Med Trop S Paulo; 45, 75-78. 
Linnen, J.; Wages, J.; Zhang-Keck, Z.Y.; Fry, K.E.; Krawezynski, K.Z.; Alter, H.; Koonin, E.; Gallagher, M.; Alter, M.; Hadziyannis, S.; Karayiannis, P.; Fung, K.; Nakatsuji, Y.; Shih, J.W.K.; Young, L.; Piatak, M.; Hoover, C.; Fernandez, J.; Chen, S.; Zou, J.C.; Morris, T.; Hyams, K.C.; Ismay, S.; Lifson, J.D.; Hess, G.; Foung, S.K.H.; Thomas, H.; Bradley, D.; Margolis, H.; Kim, J.P. (1996), Molecular cloning and disease association of hepatitis $G$ virus: a transfusion transmissible agent. Science; 271, 505508.

Oliveira, L.A.; Martins, R.M.B.; Carneiro, M.A.S.; Teles, S.A.; Silva, A.S.; Cardoso, D.D.P. Lampe, E; Yoshida, C.F.; (2002), Prevalence and genotypes of GB virus $\mathrm{C} /$ hepatitis $\mathrm{G}$ virus among blood donors in Central Brazil. Mem Inst Oswaldo Cruz; 97: 953-957.

Oto, M.; Miyake, S.; Yuasa, Y. (1993), Optimization of nonradioisotopic single strand conformation polymorphism analysis with a conventional minislab gel electrophoresis apparatus. Ann Biochem; 213, 1922.

Pavesi, A. (2001), Origin and evolution of GBV$\mathrm{C} /$ hepatitis $\mathrm{G}$ virus and relationship with ancient human migrations. J Mol Evol; 53, 104-113.

Pilot-Matias, T.J.; Muerhoff, A.S.; Simons, J.N.; Leary, T.P.; Buijk, S.L.; Chalmers, M.L.; Erker, J.C.; Dawson, G.J.; Desai, S.M.; Mushahwar, I.K. (1996), Identification of antigenic regions in the GB hepatitis viruses GBV-A, GBV-B and GBV-C. J Med Virol; 48, 329-338.

Quiros-Roldan, E.; Quiros-Roldan, A.; Maroto, C. (2001), Investigation of saliva, urine or semen samples for the presence of GBV-C RNA. Eur $J$ Epidemiology; 17, 271-274.

Ren, H.; Zhu, F.L.; Cao, M.M.; Wen, X.Y.; Zhao, P.; Qi, Z.T. (2005), Hepatitis G virus genomic RNA is pathogenic to Macaca mulatta. World $J$ Gastroenterol; 11, 970-975.

Sarrazin, C.; Roth, W.K.; Zeuzem, S. (1997), Heterosexual transmission of GB virus-C/hepatitis G virus infection. Eur J Gastroenterol Hepatol; 9, 1117-1120.

Simons, J.N.; Leary, T.P.; Dawson, G.L.; Pilot-Matias, T.J.; Muerhoff, A.S.; Schlauder, G.G.; Desai, S.M.; Mushahwar, I.K. (1995), Isolation of a novel virus like sequences associated with human hepatitis. Nature Medicine; 1, 564-569.

Souza, I.E.; Allen, J.B.; Xiang, J.; Klinzman, D.; Diaz, R.; Zhang, S.; Chaloner, K.; Zdunek, D.; Hess, G.; Williams, C.F.; Benning, L.; Stapleton, J.T. (2006),
Effect of Primer Selection on Estimates of GB Virus C (GBV-C) Prevalence and Response to Antiretroviral Therapy for Optimal Testing for GBVC, Viremia, 44-9 3105-3113.

Stapleton, J.T. (2003), GB virus type C/hepatitis G virus. Semin Liver Dis; 23, 137-148.

Stapleton, J.T.; Williams, C.F.; Xiang, J. (2004), GB virus C: a beneficial infection? J Clin Microbiol; 42, 3915-3919.

Stark, K.; Bienzle, U.; Hess, G.; Engel, A.M.; Hegenscheid, B.; Schluter, V. (1996), Detection of the hepatitis $G$ virus genome among injecting drug users, homosexual and bisexual men and blood donors. J Infect Dis; 174, 1320-1323.

Xiang, J.; George, S.L.; Wünschmann, S.; Chang, Q.; Klinzman, D.; Stapleton, J.T. (2004), Inhibition of HIV-1 replication by $\mathrm{GB}$ virus $\mathrm{C}$ infection through increases in RANTES, MIP-1 $\alpha$, MIP-1 $\beta$ and SDF-1. Lancet; 363, 2040-2046.

Xiang, J.; Martinez-Smith, C.; Gale, M. Jr; Chang, Q.; Labrecque, D.R.; Schmidt, W.N.; Stapleton, J.T. (2005), GB virus type C NS5A sequence polymorphisms: association with interferon susceptibility and inhibition of PKR-mediated eIF2alpha phosphorylation. J Interferon Cytokine Res; 25, 261-270.

Wanderlei-Silva, D.; Nobre, M.; Gonzaga, R.S.; Viana, L.S.; Neto, E.R. (2005), High Quality DNA from Human Papillomavirus (HPV) for PCR/RFLPs. Braz. Arch. Biol. Technol. 48-1, 37-40.

Watanabe, M.A.E.; Milanezi, C.M.; Silva, W.A. Jr; de Lucena Angulo, I.; Santis, G.; Kashima, S.; da Costa, J.A.; Neto, M.M.; Covas, D.T. (2003), Molecular investigation of GB virus C RNA in hemodialysis and thalassemics patients from Brazil. Ren Fail; 25, 6775.

Wiwanitkit V. (2005), Hepatitis G virus RNA positivity among the voluntary blood donors: a summary. Ann Hepatol; 4, 43-46.

Wu, R.R.; Mizokami, M.; Cao, K.; Nakano, T.; Ge, X.M.; Wang, S.S.; Orito, E.; Ohba, K.; Mukaide, M.; Hikiji, K.; Lau, J.Y.; Lino, S. et al. (1997), GB virus $\mathrm{C} /$ Hepatitis $\mathrm{G}$ virus infection in southern China. $J$ Infect Dis; 175, 168-17. 